\title{
KONTEMPLASI DAN PENGETAHUAN AKAN ALLAH: BELAJAR DARI RIKARD ST. VIKTOR
}

\author{
Marciano Almeida Soares ${ }^{\mathrm{a}, 1}$ \\ Antonius Eddy Kristiyanto ${ }^{\text {a,2 }}$ \\ a Sekolah Tinggi Filsafat Driyarkara, Jakarta, Indonesia \\ 1 soaresofm@gmail.com \\ 2eddykofm@driyarkara.ac.id
}

Kata-kata Kunci:

kontemplasi, imajinasi, rasio, pengetahuan, immortality, incorruptible, kontingensi, kekekalan.

\begin{abstract}
Can human being experience the divine reality and know God? he/she can know and experience God through faith and contemplation. This study draws attention to the two essentials in Richard's idea of St. Viktor, which are about human contemplation and knowledge of God. Contemplation is the way to arrive at the divine (or eternal) reality by departing from the contingent reality. Human being can attain divine realities through imagination, rationality, and intuition. Through contemplation that includes imagination, human reason and intuition, human being can reach three levels of heaven, a heaven filled with human spirit, namely immortality, a heaven filled with angelic spirit, the incorruptible and heaven inhabited by God, and the eternity. In order to achieve an understanding of eternity it takes faith as a precondition. Richard says faith is the foundation and source of all good, and knowledge is a manifestation and a perfection.
\end{abstract}

\section{PENGANTAR}

Teologi Abad Pertengahan sangat kental dengan upaya untuk menjelaskan isi iman agar dipahami. Selain itu, dalam refleksi teologis para teolog Abad Pertengahan menggunakan argumentasi-argumentasi filosofis untuk menjelaskan eksistensi Allah. Semboyan yang sangat terkenal, yang dikemukakan oleh Anselmus Canterbury adalah fides quaerens intellectum (iman yang mencari pemahaman). ${ }^{1}$ Oleh karena filsafat dipakai untuk menjelaskan teologi, maka filsafat pada Abad Pertengehan dipandang sebagai hamba teologi atau philosophia ancilla teologiae.

Istilah lain yang juga digunakan pada awal Abad Pertengahan ${ }^{2}$ oleh Agustinus Hip- po (dalam Tract. Ev. Jo., 29.6) adalah Credo ut intellegam, yang artinya saya percaya untuk memahami. Richard dari St. Victor mengikuti pandangan Agustinus, yaitu penekanan pada iman. Bahwa dengan iman orang akan memahami esensi dari apa yang diimani itu. Bahkan Richard mengatakan iman adalah asal dan dasar dari segala kebaikan. $^{3}$

Dalam kajian ini, kami akan memperhatikan dua hal berikut. Pertama, kontemplasi; Kedua, pengetahuan akan Allah. Adapun sistematika penulisan kajian ini adalah Pertama, biografi singkat mengenai Richard dari St. Victor; Kedua, kontemplasi; Ketiga, pengetahuan manusia akan Allah; Keempat, kesimpulan dan tanggapan. 


\section{BIOGRAFI RICHARD DARI SANTO VIKTOR $^{4}$}

Richard berasal dari Skotlandia. Tidak ada data yang akurat mengenai kelahiran dan masa kanak-kanak Richard. Rick van Nieuwenhove dalam An Introduction to Mediaeval Theology menulis bahwa Richard bergabung dalam Ordo Kanonik Reguler Santo Agustinus atau Biara St. Viktor sebelum meninggalnya Hugo. Dengan demikian, Hugo adalah pendahulu Richard dari sekolah St. Viktor. Hugo adalah seorang teolog dan filsuf. Ia menulis salah satu ringkasan terpenting mengenai teologi Kristen sebelum Thomas Aquinas. Karya Hugo yang terkenal adalah De Sacramentis Christiane Fidei yang membahas mengenai iman Kristiani secara sistematik. ${ }^{5}$ Sementara Ruben Angelici dalam komentarnya atas Richard of Saint Victor on the Trinity menyatakan bahwa Richard bergabung dalam Biara St. Viktor antara tahun 1120 dan 1135, dan menjadi Prior pada tahun $1162 .^{6}$

Di Sekolah Santo Viktor (Sekolah atau biara St. Viktor adalah sekolah yang didirikan oleh William Champeaux yang pernah menjadi murid Anselmus Laón) pada tahun 1108 setelah ia pensiun dari Paris sebagai dosen. Para Viktorin adalah mereka yang mengikuti Anggaran Dasar atau kanon reguler Agustinus. Mereka memfokuskan diri pada hidup kontemplatif, mendedikasikan hidupnya untuk mempelajari Kitab Suci, tulisan para Bapa Gereja, dan karya-karya para pagan. Sekolah atau biara St. Viktor adalah sekolah yang didirikan oleh William Champeaux (yang pernah menjadi murid Anselmus Laón) pada tahun 1108 setelah ia pensiun dari Paris sebagai dosen. Para Viktorin adalah mereka yang mengikuti Anggaran Dasar atau kanon reguler Agustinus. Mereka memfokuskan diri pada hidup kontemplatif, mendedikasikan hidupnya untuk mempelajari Kitab Suci, tulisan para Bapa Gereja, dan karya-karya para pagan, ${ }^{7}$ Richard belajar filsafat dan teologi di bawah bimbingan Hugo. ${ }^{8}$ Richard wafat pada 10 Maret $1173 .^{9}$
Selain itu, dalam lingkungan skolastik abad ke-12 Sekolah Hugo dari St. Viktor berhasil membuat sintesis spiritual. Adalah karya para Kanonik dari St. Viktor, yang bermakna sosial dan yang mengantar ke pintu-pintu kota Paris. Sekolah ini didirikan oleh Wilhelm Champeaux. Setelah beberapa tahun mengajar di Notre-Dame di Paris, ia menarik diri bersama banyak alumni ke St. Viktor. Perihal orientasi teologis Sekolah St. Viktor dapat dinyatakan sebagai berikut. Pada mulanya pengajaran teologis sekolah ini menimba ilham pada pengajaran Anselmus Laón, mantan guru Wilhelm Champeaux. Tetapi dalam waktu yang relatif singkat sekolah ini mendapat pengaruh-pengaruh lain. Tempat pertama adalah yang berasal dari Anselmus Canterbury. Tesis-tesis bagi perlunya penebusan yang diungkapkan dalam karya Cur Deus homo tampil kembali dalam tulisan-tulisan Hugo dan para penerusnya; sampai akhirnya dibicarakan misteri Trinitas.

Terlepas dari kurangnya data yang akurat mengenai Riwayat hidup Richard, hal yang pasti bahwa Richard adalah seorang biarawan dan mistikus Abad Pertengahan. Pemikiran mistik dan refleksi teologisnya tidak terlepas dari pengaruh tradisi, Kitab Suci, warisan pemikiran para bapa gereja, serta tokoh-tokoh seperti Pseudo-Dionisius, Anselmus, Hugo dan Agustinus. Richard juga berdiri pada tradisi Pseudo-Deonisius yang memandang Allah sebagai Bonum Divusivum Sui. ${ }^{10}$ Dengan kata lain, Allah adalah kebaikan yang meluap atau dalam refleksi Richard bahwa Allah adalah Kasih, yang senantiasa hidup dalam relasi, (kasih) yang tanpa pamrih (charity-love) atau Condilectio. ${ }^{11}$ Pemikiran Richard di kemudian hari sangat berpengaruh pada tokoh teolog Abad Pertengahan (atau pada Abad XIII) seperti Bonaventura. Tulisan Bonaventura mengenai mistik dalam Itinerarium Mentis in Deum sangat dipengaruhi oleh Richard; terutama ulasan Bonaventura mengenai enam jalan kontemplasi dalam Itinerarium. ${ }^{12}$ 
Karya-karya yang dikerjakan oleh Richard adalah komentara atas Kitab Suci, yang mencakup Book of Selections (Liber Exceptionum), homili, surat-surat, karya teologis seperti The Trinity, dan risalahrisalah mengenai mistik. Dua risalah mistik monumental yang ditulis oleh Richard adalah The Twelve Patriarch yang disebut juga dengan Benjamin Minor dan The Mystical Ark atau Benjamin Major. ${ }^{13}$

\section{KONTEMPLASI}

Richard membahas kontemplasi dalam dua karyanya, yaitu Twelve Patriarchs dan The Mystical Ark. Berkenaan dengan karya ini, kami berikhtiar untuk menguraikan isi karya monumental tersebut. Tetapi sebelum itu, perlulah kami mencatat warisan Hugo dari St. Viktor yang dalam tingkat tertentu mempengaruhi muridnya, Richard, yang menuangkan gagasannya dalam kedua karya tersebut. Refleksi teologi Hugo, guru dari Richard, tentang kontemplasi diilhami oleh Augustinus dan Pseudo-Dionisius. Uraian tentang keunggulan kasih jelas sekali dipengaruhi oleh Augustinus. Kasih ini bagi Hugo mengantar ke contemplatio. Kontemplasi seharusnya didasarkan pada unsurunsur yang dewasa ini kita sebut kodrati.

Dengan demikian, seraya merefleksikan kontemplasi, Hugo menggarap psikologi jauh lebih kaya ketimbang Wilhelm Champeaux, Anselmus dari Laón atau Abelardus. Lebih lanjut, ia mengawinkan kontemplasi dengan filsafat dan teologi [keduanya bukan ilmu pengetahuan yang semata-mata spekulatif]. Keduanya merupakan anak tangga yang perlu dinaiki dan secara bertahap mengantar orang kepada kesempurnaan ilahi.

Dengan cara demikian Hugo memahami filsafat sebagai suatu sapientia. Termasuk dalam sapientia ini adalah cinta. Dia sampai pada pertimbangan bahwa filsafat bagaikan suatu meditasi tentang hidup dan kematian. Filsafat mengalamatkan kita pada tujuan terakhir kita melalui semua realitas dunia ini, termasuk seni, logika, moral, teknik, matematika, fisika dan teologi kodrati. Filsafat adalah sapientia inferior, yang disubordinasikan oleh sapientia superior [atau teologi ilahi].

\section{Kontemplasi dalam Karya Twelve Patriarch}

Dalam Twelve Patriarch, Richard membuat interpretasi tropologis ${ }^{14}$ pada sejumlah kisah dalam Kitab Suci. Dalam karya ini, Richard berbicara mengenai kesadaran dan disiplin diri, serta pengalaman kontemplasi. Ia membuat interpretasi atas dua narasi Kitab Suci, sebagai personifikasi alegoris. Dengan "alegoris" di sini dimaksudkan: suatu narasi yang bersifat fiksi, simbolis yang menyampaikan makna yang tidak secara eksplisit dituankan dalam sebuah narasi. Alegori meliputi bentuk-bentuk seperti fabel, perumpamaan, dan permintaan maaf, mungkin memiliki arti pada dua atau lebih tingkat yang dapat dipahami oleh pembaca hanya melalui proses penafsiran. Personifikasi alegoris itu meliputi: Pertama, narasi mengenai kedua belas anak laki-laki Yakub dan satu anak perempuannya; kedua istri Yakub serta pelayan-pelayannya. Richard menggunakan narasi ini untuk mengilustrasi kedisiplinan dan persiapan moral jiwa manusia yang diperlukan untuk kontemplasi.

Dalam kisah ini, Richard mengambil urutan kelahiran anak-anak Yakub sebagai urutan atau tahap-tahap disiplin diri dan pengembangan kontemplasi. Richard menghubungkan dengan peristiwa kelahiran anak-anak dan nama mereka yang mengandung makna tersendiri. Nama-nama itu menunjukkan peran yang ditugaskan oleh Yakub dan setiap peristiwa dalam kehidupan menyediakan materi untuk kontemplasi. ${ }^{15}$

Selain itu, Richard menemukan sebuah epistimologi yang menyeluruh dalam diri dan hidup Yakub, dan kedua istrinya serta pelayan-pelayannya. Ia menjelaskan bahwa Yakub sebagai bapa dari keduabelas anak merepresentasi (jiwa) rasional. Kedua istrinya merepresentasi kekuatan utama dari jiwa. Rahel melambangkan rasio, sementara Leah melambangkan afeksi yang mencakup kehendak, emosi dan sensibilitas. Rahel yang melambangkan rasio, membimbing (orang) kepada semua kebenaran. Leah yang melambangkan afeksi, (men)datang (kan) semua kebenaran. Pelayannya Rahel, yaitu Bala, melambangkan imajinasi yang 
menghubungkan rasio kepada dunia sensible, yang digambarkan dalam benda-benda sensible. Sementara hambanya, Leah, yaitu Zelpha merepresentasikan lima panca indra yang menghubungkan afeksi manusia dengan dunia luar. ${ }^{16}$

Kedua, narasi mengenai pengalaman para murid di atas gunung ketika melihat transfigurasi Yesus (lihat Mat. 17: 1-13; Mrk. 9:2-13). Menatap dengan saksama peristiwa transfigurasi itu, Richard menjelaskan bahwa ada suatu proses yang dilalui oleh para murid untuk sampai pada puncak gunung dan dapat menyaksikan transfigurasi Yesus. Mereka mendaki gunung, beristirahat di atas puncak gunung, melihat Yesus berubah rupa menjadi terang dan kemudian mereka masuk dalam pengalaman, di mana rasio (akal budi) tidak dapat dijelaskannya, yaitu ketika mendengar suara (Allah Bapa) dari awan. Secara simbolis Richard menafsirkan sebagai pengalaman asketis dan pencarian kontemplatif para murid akan Allah. ${ }^{17}$

Dari dua narasi alkitabiah tersebut, Richard mau memperlihatkan beberapa hal yang hakiki, yakni disiplin diri (dalam kerohanian), pengalaman asketik (yang entah bagaimana perlu dilatih dan dimohonkan kepada Alah) dan berbagai upaya dalam kontemplasi. Gambaran mengenai tokohtokoh dalam Kitab Suci yang dihubungkan dengan rasio, afeksi, imajinasi, kehendak dan lain-lain menunjukkan kepada kita untuk memberi diri secara total dalam melakukan kontemplasi.

\section{Kontemplasi dalam The Mystical Ark}

Dalam The Mystical Ark, Richard membuat distingsi yang jelas atas enam cara kontemplasi. Enam cara kontemplasi itu mencakup semua tingkat pengetahuan manusia. Richard membedakan tiga tingkat mengetahui: Pertama, imajinasi. Imajinasi atas segala sesuatu yang dapat kita rasakan atau lihat dengan indra manusiawi (sensible things). Kedua, akal budi atau rasio. Rasio ditujukan pada hal-hal yang tidak tampak, namun bagaimana pun juga masih dapat dipahami (intelligible things) dengan rasio manusia. Ketiga, tingkat pemahaman ditu- jukan pada hal-hal Intellectible. Hal-hal yang Intellectible mengacu pada hal-hal yang tak terlihat, yang juga tidak dapat dipahami dengan rasio manusia. ${ }^{18}$

Richard membedakan kontemplasi dari pikiran atau imajinasi dan meditasi. Kendati demikian ketiganya dapat berhubungan dengan satu objek; "kita memandang sesuatu dan objek tertentu dengan satu cara yaitu berpikir, kemudian kita menyelidiki objek bersangkutan dengan cara meditasi dan pada akhirnya kita mengagumi objek itu dengan jalan kontemplasi." Dalam arti ini kontemplasi tidak selalu berhubungan dengan hal-hal yang bersifat ilahi. Artinya, kita dapat mendekati ciptaan atau bendabenda empiris dengan jalan kontemplasi juga. Pendekatan yang dapat kita lakukan ialah melalui tahap imajinasi, rasio dan pemahaman (intuisi). Richard menyebut ketiga cara ini dengan, "sejenis penglihatan jiwa."19

Dengan arus pandangan yang demikian Richard membuat distingsi atas ketiga metode ini. Ia menyatakan bahwa pertama pikiran manusia itu bersifat diskursif. Pikiran memiliki daya "pelanturan yang mengarah ke segala penjuru tanpa ada tempat yang tepat untuk mendarat," karena yang dominan digunakan dalam pikiran adalah imajinasi. Kedua, meditasi lebih fokus pada penyelidikan jiwa. Dalam meditasi kita berupaya untuk menggambarkan sesuatu dengan akal budi mengenai pencariannya akan kebenaran. Ketiga, kontemplasi mengacu pada pemahaman. Alih-alih diskursif, ia menangkap sesuatu dalam satu penglihatan dan beristirahat dalam persepsi tentang kebijaksanaan yang dirasakannya. ${ }^{20}$

Melihat pengertian yang dibuat oleh Richard ini, kita dapat mengatakan bahwa meditasi dalam konteks ini berbeda dengan praktek meditasi sebagaimana dipahami dalam pemikiran modern. Meditasi bagi Richard adalah suatu perhatian intelektual. Selain itu, tidak ada batas yang ketat antara pikiran, meditasi dan kontemplasi. Meditasi, misalnya, jika dapat mencapai sebuah kebenaran, ada kemungkinan beralih (melam- 
paui diri) ke kontemplasi. ${ }^{21}$ Dengan demikian, setiap tahap mempunyai sebuah dinamikan (batin) terhadap transendensi diri atau setiap tahap (pikiran, meditasi dan kontempalasi) salalu ada dinamika untuk melampaui dirinya.

Richard memperlihatkan bahwa batas antara ketiganya (pikiran, meditasi dan kontemplasi) tidak kaku. Richard memberikan gambaran yang luas mengenai kontemplasi, yang dapat mencakup elemen pikiran dan meditasi. Dalam Mystical Arkh I.6, ia memberi penjelasan mengenai enam jenis kontemplasi. Dua yang pertama berhubungan dengan imajinasi; dua berikutnya berhubungan dengan rasio; dan dua yang terakhir berhubungan dengan pemahaman. Dalam proses kontemplasi yang harus dilalui oleh tingkat imajinasi, rasio dan pemahaman (Intellectible), kedua tingkat di atas (meditasi dan kontemplasi) dapat merendahkan sampai ke tingkat yang paling bawah dan bisa juga melampaui tingkat yang paling tinggi. $^{22}$

Keenam jenis kontemplasi itu adalah sebagai berikut. Jenis pertama kontemplasi pada tahap imajinasi menurut imajinasi saja (in imagination and according to imagination). Kontemplasi jenis ini ditujukan pada benda-benda atau hal-hal yang sensible. Pada tingkat ini, kita memberi perhatian pada keindahan dan keragaman bendabenda yang tampak, yang kita rasakan dan lihat dengan indra kita. Kita mengagumi segala keindahan ciptaan atau benda-benda yang tampak, tetapi kita tidak melakukan penyelidikan yang lebih jauh dengan rasio atas apa yang kita alami.

Jenis kontemplasi yang kedua, adalah dalam imajinasi dan dan menurut rasio (in imagination and according to reason). Sambil mengkontemplasikan benda-benda yang berada dalam imajinasi, kita mulai mempertimbangkan dan menyelidiki bendabenda itu dari perspektif rasional. Kita dapat bertanya, apa penyebab dari benda itu dan keindahannya? Meskipun kontemplasi jenis ini masih dalam tahap imajinasi, namun akal budi turun pada level imajinasi.
Jenis kontemplasi yang ketiga berada dalam tahap rasio dan menurut imajinasi (In reason and according to imagination). Pada tahap ini kita berpikir mengenai benda-benda yang tidak tampak, tetapi kita melakukannya dengan membuat gambaran akan kesamaannya dengan benda-benda yang tampak. Oleh sebab itu, Richard menyebutnya dengan rasio (untuk hal yang kita pikirkan) menurut imajinasi (dengan menggunakan gambaran akan kesamaan dari bendabenda yang tampak). Pada level ini, imajinasi mentransendensi diri ke dalam ranah rasio.

Jenis kontemplasi yang keempat terbentuk dalam rasio dan menurut rasio (in reason and according to reason). Pada tahap ini, kita mengarahkan perhatian kita pada benda-benda atau hal-hal yang tidak diketahui oleh imajinasi, tetapi diketahui oleh rasio. Pada kontemplasi jenis ini, hal yang terjadi adalah pemaham yang murni akan suatu benda yang dipertimbangkan dan diselidiki secara mendalam oleh rasio. ${ }^{23}$

Jenis kontemplasi yang kelima tingkatnya di atas akal budi, tetapi tidak melampaui akal budi (Above the reason but not beyond the reason). Pada tahap ini, kita berurusan dengan hal-hal yang tidak kita temukan hanya dengan mengandalkan akal budi, tetapi ia menampakan diri kepada kita melalui pewahyuan. Kita dapat memberikan persetujuan intelektual kita peda pewahyuan itu. Richard memberi contoh akan salah satu pemahaman kita akan yang ilahi melalui Kitab Suci.

Jenis kontemplasi yang keenam, berbicara mengenai hal-hal yang diatas rasio dan tampaknya melampaui atau bahkan bertentangan dengan rasio manusia. Richard menyebut, misalnya pembicaraan mengenai iman kita akan Allah Trinitas. ${ }^{24}$ Pembicaraan mengenai Allah Trinitas senantiasa merupakan suatu misteri, yang tidak serta-merta dijelaskan dengan sejelas-jelasnya oleh rasio manusia. ${ }^{25}$

Melalui gambaran singkat mengenai kontemplasi yang dibuat oleh Richard, kita dapat menangkap tingkatan kontemplasi manusia. Dari kontemplasi akan benda- 
benda sensible dalam tahap pertama dan kedua, kita dihantar masuk pada pengertian akan benda-benda intelligible, kemudian kita sampai pada hal-hal yang intellectible. Dalam arti ini, kontemplasi bukan hanya teknik meditasi, tetapi perhatian intelektual yang sungguh-sungguh, yang mana melaluinya kita mendekati dunia dengan Allah.

Akal budi melampau dirinya sendiri, dan mencapai pemenuhan dalam pemahaman yang pada gilirannya mentransendensi dirinya:

Walaupun tiga-tiganya yang tertinggi ada bersama (yaitu kontemplasi 4-6), namun tidak ada tanpa pemahaman yang murni, di awal pemahaman lebih condong pada rasio; pada tingkat yang kelima, pemahaman mengangkat rasio pada dirinya; pada (tingkat) yang keenam pemahaman melampaui rasio dan seperti di mana, ia meninggalkan segala sesuatu di bawah dirinya. Lagi, meskipun di tengah ada empat yang diangkat bersama, namun tidak eksis tanpa penalaran, pada jenis kontemplasi yang kedua, rasio merendahkan diri pada imajinasi, sebagaimana ia ada untuk benda-benda yang lebih rendah; pada jenis yang ketiga, ia menggambarkan imajinasi untuk hal yang lebih tinggi; pada yang keempat ia menerima dan membimbing pemahaman, yang turun, di bawah dirinya; pada yang kelima, rasio melampaui dirinya, untuk memahami dan menyinggung benda-benda itu dengan hal-hal yang mulia atau yang agung. ${ }^{26}$

Secara singkat Richard kiranya hendak menyatakan bahwa di dalam kontemplasi jiwa manusia dapat mengalami ekstasi atau pengangkatan melalui tiga tahap, yakni tingkat imajinasi, tingkat rasio, dan tingkat intuisi. Jiwa menggunakan pembelajaran akan hal-hal yang sekuler sekaligus wahyu ilahi sampai akhirnya dipersatukan dengan Tuhan dalam kontemplasi ilahi. ${ }^{27}$ Richard juga mengatakan, sebagaimana Kristus naik ke surga dengan tubuh-Nya, ia mengajak kita untuk naik ke surga dengan roh kita. Richard mengatakan, dengan tubuh-Nya Yesus naik ke surga, maka marilah kita naik ke surga secara spiritual melalui kontemplasi spiritual. $^{28}$
Ada tiga tingkat surga dalam konsep dan pemikiran Richard St. Viktor. Artinya, dalam kontemplasi orang terangkat atau naik dari hal-hal yang kelihatan kepada yang tidak kelihatan, dari realitas fisik ke yang spiritual. Atau dengan kata lain, dari yang immortal kepada yang incorruptible dan dari yang incorruptible kepada eternity. Jadi, kita dapat memahami bahwa tiga tingkat surga yang dimaksud oleh Richard, adalah Immortality, incorruptibility dan eternity. Atau dengan kata lain, ada tempat manusia yang mana dipenuhi dengan semangat manusiawi, tempat para malaikat, dan kediaman Allah (eternity). Richard mengatakan bahwa kita dapat mencapai ketiga tingkat ini dengan jalan kontempalasi. Kita dapat naik ke surga yang pertama bahkan sekarang juga, kita dapat naik ke surga yang kedua dengan keutamaan, dan kita dapat naik ke surga yang ketiga dengan kontemplasi spiritual).

Kami dapat menyimpulkan bahwa kedua karya ini, The Twelve Patriarch dan The Mystical Ark menunjukkan kepada kita dua focus yang berbeda mengenai kontemplasi. Todd de Vasquez mengatakan bahwa Richard membuat distingsi antara rahmat berdiskresi dan rahmat kontemplasi. Fokus Richard dalam Twelve Patriarch adalah keutamaan berdiskresi. Berdiskresi berarti berupaya untuk menyadari dan mengekang afeksi yang membawa tubuh manusia ke dalam hasrat immoral; diskresi juga dapat berarti menjaga kemurnian stensi seseorang dalam hubungan dengan keinginan daging atau keinginan duniawi. ${ }^{29}$ Dua kisah yang diangkat oleh Rikard, yaitu mengenai keluarga Yakob dan pengalaman para murid menunjukkan bagaiaman orang mengendalikan diri dari hasrat duniawi, orang perlu melakukan askese dan segala macam untuk mencapai kemurnian dalam kontemplasi.

Sementara dalam The Mystical Ark, penekanan lebih pada rahmat kontemplasi. Konsernya lebih pada kontemplasi, pada relasi mental manusia dalam berkontemplasi. Dalam karya ini Richard lebih berbicara pada soal kemampuan akal budi manusia dalam berkontemplasi. Pembagian keenam jenis kontemplasi itu juga 
menunjukkan secara jelas bagaiaman focus dari The Mystical Ark, yaitu pada rahmat kontemplasi. Kendati demikian kedua karya ini tidak boleh dilihat secara parsial. Keduanya mempunyai hubungan satu sama yang lain. Pengendalian diri, kesadaran, askese dan disiplin diri sangat dibutuhkan agar manusia dapat meng-arahkan perhatian dan pemenungannya pada yang Ilahi. Dua karya ini juga menunjukkan kepada kita dua hal yang berbeda mengenai pengetahuan manusia akan diri dan akan Allah. Twelve Patriarch menunjukkan pengetahuan manusia akan dirinya, akan kemauan, hasrat dan kemampuan manusia untuk mengendalikan diri. Sementara, The Mystical Ark lebih berbicara mengenau upaya manusia untuk mencapai pemahaman akan Allah melalui kontemplasi, bahkan Richard mengatakan melalui kontemplasi spiritual manusia dapat bersatu degan Allah. ${ }^{30}$

\section{PENGETAHUAN AKAN ALLAH}

Melalui iman dan akal budi, Richard menganalisis pengetahuan manusia akan Allah (Allah Trinitas). Richard mengatakan adalah niscaya untuk mengetahui terlebih dahulu metodologi untuk memberi penjelasan mengenai Allah. Ia mengajak pembaca untuk memahami terlebih dahulu hubungan antara kebenaran yang tampak dan penyelidikan manusia atas kebenaran itu. Ada dua hal yang dibutuhkan oleh manusia, yakni otoritas (auctoritates) dan argumen yang diperlukan (Raciones Necessariae). Bagi Richard, pemahaman yang baik akan korelasi rasio dengan otoritas, realitas dan analisis atasnya, niscaya diperlukan untuk sebuah pemahaman yang sehat akan subjek. ${ }^{31}$ Richard secara personal mengatakan bahwa iman adalah asal atau fundasi dari semua kebaikan dan pengetahuan adalah perwujudan dan kesempurnaan. Atas dasar inilah, Richard mengajak para pembaca untuk mengusahakan sebaik mungkin guna memahami apa (isi, substansi) yang kita imani. $^{32}$

Latar belakang pemikiran Richard ini dapat ditelusuri dalam pemikiran para patres. Para Bapa Gereja telah memikirkannya sejak abad-abad awal, yaitu pembicaraan mengenai eksistensi obeyektif, bahwa kebenaran rasional tidak bisa dibantah oleh intelek manusia tanpa kontradiksi. St. Agustinus mengatakan, "Autoritas membutuhkan iman dan mempersiapkan manusia akan rasio yang menuntunnya pada pemahaman dan pengetahuan." 33

Pengaruh Agustinus dan Anselmus sangat besar pada sekolah St. Viktor. Menurut Agustinus, pengungkapan kebenaran mengundang orang pada iman, yang berkembang setelah seseorang merenungkannya dan menerimanya. Rahmat, pada kenyataan, menuntun pemahaman rasional manusia sedimikian rupa, sehinga orang menyadari bahwa kebenaran yang sama diperoleh dari iman, dan penyelidikan serta pencarian akan Allah datang dari Allah sendiri. ${ }^{34}$ Dikatakan bahwa "iman mencari, dan pemahaman menemukan; sebagaimana dikatakan oleh nabi Yesaya, 'jika kamu tidak percaya, kamu tidak akan mengerti.' (Yes. 7:9). ${ }^{35}$ Tokoh lain adalah Anselmus dari Canterbury yang memperkenalkan adagium yang berbunyi, Fides Quaerens Intelectum mengatakan, seorang Kristiani harus berpegang teguh pada imanya akan Allah sambil membuktikannya melalui rasionya. ${ }^{36}$

Anselmus dalam On the Incarnation of the Word, mengatakan bahwa dengan selalu berpegang teguh pada iman yang sama tanpa keraguan, dengan mengasihinya dan dengan rendah hati hidup untuknya, seorang kristiani harus membuktikan bagaimana caranya. Apa yang diimani dan diakui oleh Gereja Katolik sejauh ini, karena orang dapat mencari argumen. Jika orang mengerti, orang akan bersyukur kepada Allah; jika tidak, ia harus menundukkan kepala dengan hormat. Ketika seorang pemula dengan naif mencoba naik pada hal-hal yang intelektual, pertama, ia membutuhkan tangga iman mereka tenggelam dalam berbagai kesalahan dengan alasan kurangnya pemahaman mereka. Karena mereka secara jelas tidak memiliki kekuatan iman.

Richard dari St. Viktor tentu sejalan dengan pandangan tradisional. Penekanan Richard pertama-tama pada iman, dan kemudian pada rasio. Pada pengantarnya 
atas The Trinity, Richard mengajak kita untuk melakukan penyelidikan rasional, yang mendorong kita untuk masuk dalam kontemplasi. Melalui kontemplasi kita dapat masuk ke dalam tempat di mana Allah berdiam diri, di sana kita akan Melihat keberadaan Kristus atau Kristus yang bertakhta di sisi kanan Bapa.

Richard mengatakan,

Mari kita senantiasa berjuang, dalam keterbatasan mengenai apa yang benar dan mungkin, untuk memahami dengan akal budi, apa yang kita imani. Jika kita adalah anak-anak Sion, marilah kita mendirikan tangga kontemplasi, marilah kita mengenakan sayap seperti elang, dengannya kita dapat terbang dari dunia dan naik ke tampat surgawi. Mari kita mencicipi realitas surgawi, bukan yang dari dunia. (Mari kita merasakan atau mencicipi realitas surgawi) di mana Kristus duduk di sebelah kanan Allah. ${ }^{37}$

Lantas kita bertanya, bagaimana kita dapat memahami realitas yang tertinggi? Richard mengatakan, kita dapat memahami realitas melalui tiga cara, yaitu melalui pengalaman, akal budi, dan iman. Agar kita dapat memahami realitas tertinggi, kita perlu menyadari terlebih dahulu bagaimana kebiasaan kita untuk memperoleh pengetahuan. Richard mengatakan, dalam kehidupan kita setiap hari, kita mempunyai tiga cara untuk memahami realitas. Pertama, kita mengetahui relaitas tertentu dengan pengalaman langsung akan data empiris; kedua, kita menjelaskan realitas indrawi itu dengan akal budi; dan ketiga, kita memegangnya dalam iman. Ruben Angelici dalam komentarnya mengatakan bahwa ketika Richard mengatakan, rasio kita menuntun kita dari yang tampak kepada yang tidak tampak, dari yang duniawai ke yang supraduniawi, dari yang manusiawi kepada yang ilahi menunjukkan bahwa Richard berdiri tepat pada tradisi Anselmus mengenai iman mencari pemahaman (fides quaerens intelectum). Richard menambahkan: ${ }^{38}$

"Untuk memehami kebenaran yang telah dikatakan dengan benar "jika kamu tidak percaya, kamu tidak akan mengerti," kamu harus masuk melalui iman. Tetapi kita tidak segera berhenti di sini; sebaliknya kita harus terus-menerus mencapai pemahaman yang intim dan mendalam dengan ketekunan dan ketelitian yang tinggi untuk menembus lebih dalam dari hari ke hari, melalui wawasan baru yang kita dapat untuk memahami iman kita."

Ada dua hal yang tampak dari pemahaman semacam ini. Di satu sisi, dengan pengalaman langsung kita mencapai pengertian yang sementara (temporal) akan relaitas. Sementara di sisi lain, kita dapat mencapai pengetahuan yang kekal melalui akal budi dan iman. ${ }^{39}$

Richard mengatakan, untuk menjelaskan realitas yang eksistensinya niscaya, kita tidak hanya membutuhkan argumentasi yang rasional saja, bahkan yang niscaya, meskipun realitas itu tersembunyi dari perhatian kita saat ini. Bagi Richard relaitas kekal itu harus ada sebagaimana mereka telah ada, dan selalu ada. ${ }^{40}$ Refleksi atas kekekalan ini, tentu berasal dari dua hal: pertama, dari realitas yang kontingen; kedua, realitas yang ada, yang kontingen ini pasti berasal dari yang lain. Artinya, realitas yang kontingen menerima keberadaannya dari yang lain, yang kekal. Atas dasar inilah, Richard berpendapat bahwa pasti ada realitas atau pengada yang niscaya dan merupakan asal-usulnya sendiri. ${ }^{41}$ Pengada itu adalah sumber itu sendiri, ia berasal dari dirinya sendiri. Sebab, jika tidak ada pengada yang merupakan asal-usulnya sendiri, tidak akan ada prinsip yang mampu mewujudkan eksistensi dari sejumlah pengada lain yang eksistensinya tidak berasal dari dirinya. ${ }^{42}$

Setiap hal yang ada dan yang secara potensial akan ada menerima keberadaannya baik dari dirinya sendiri atau dari yang lain. Oleh sebab itu, ada kemungkinan untuk mengidentifikasi keberadaan setiap realitas. Ada tiga cara berada dari setiap realitas ilahi (atau Allah). Pertama, ada realitas yang menerima keberadaannya dari dirinya sediri, bukan dari yang lain (Allah Bapa); Kedua, ada realitas yang menerima keberadaannya dari yang satu, tidak dari dirinya. Atau dengan kata lain, ia mempunyainya dari kekekalan, tetapi dia tidak 
mengklaim bahwa itu berasal dari dirinya (Putera). Ketiga, ada realitas yang yang menerima keberadaan dari keduanya (Roh Kudus). ${ }^{43}$ Rick Van Nieuwenhove mengatakan bahwa refeleksi Trinitas Richard muncul dari dan menghasilkan, sebuah disposisi kontemplasi. Richard menggambarkanya sebagai tangga yang mana melaluinya kita naik dari refleksi akan yang kelihatan kepada kontemplasi akan misteri Tuhan yang tak kelihatan. ${ }^{44}$

Setelah berbicara mengenai keberadaan relaitas kekal yang dapat dipahami berangkat dari iman; Richard juga berbicara mengenai korelasi iman, harapan dan kasih. Penekanan Richard pada iman tidak mengabaikan dua keutamaan kristiani yang lain, yaitu harapan dan kasih. Dalam pengantarnya akan The Trinity, Richard menjelaskan keterkaitan dari ketiga keutamaan ini. Dengan mengutip Surat kepada orang Ibrani, ia mengatakan bahwa tetapi tanpa iman, tidak mungkin orang berkenan kepada Allah. (bdk. Ibr. 11:6). Dengan kata lain, iman (penyerahan dan pengandalan hidup kepada Allah) menjadi prakondisi bagi manusia untuk berkenan kepada Allah. Dia menyambung bahwa pada kenyataannya jika tidak ada iman maka tidak ada harapan.

Sebagaimana ditekankan dalam surat kepada jemaat Ibrani, "Sebab barangsiapa berpaling kepada Allah, ia harus percaya bahwa Allah ada, dan Allah memberi upah kepada orang yang sungguh-sungguh mencari Dia." Lebih lanjut Richard menyatakan, akan tetapi, jika tidak ada harapan, maka tidak ada kasih. Karena tidak ada orang yang tidak mungkin mengasihi sesuatu yang darinya tidak ada harapan akan kebaikan. Oleh sebab itu, Richard menyimpulkan bahwa dengan iman kita terangkat kepada harapan, dan dengan harapan kita berkembang dalam kasih. Setelah itu, terlepas dari itu semua, kendati orang dapat melakukan segala sesuatu dan mempunyai segala sesuatu, namun, jika tidak mempunyai kasih, maka tidak ada faedahnya sedikitpun. (bdk. 1 Kor. 13:3). Richard mengatakan adalah penting untuk mempelajari dari apa yang dikatakan oleh Sang Kebenaran mengenai kasih. ${ }^{45}$
Sebagaimana tertulis dalam Injil Yohanes 14:21, “... Dan barangsiapa mengasihi Aku, ia akan dikasihi oleh Bapa-Ku dan Aku pun akan mengasihi dia dan akan menyatakan Diri kepadanya." Dalam interpretasi atas ayat ini, Richard mengatakan, kasih menuntun pada perwujudan, perwujudan menuntun pada kontemplasi, dan kontemplasi menuntun pada pengetahuan. Tetapi ketika Kristus menyatakan diri-Nya, kita akan sama seperti Dia, sebab kita akan melihat Dia dalam keadaan-Nya yang sebenarnya. (bdk. 1Yoh. 3:2).

Dengan penjelasan seperti di atas, kita dapat memahami jalan pikiran dan reasoning Richard akan iman sebagai dasar atau sumber segala kebaikan. Semoga menjadi jelas bagi kita, bahwasanya titik berangkat yang membantu kita untuk naik kepada realitas kekal melalui harapan dan kasih adalah Iman. Melalui iman kita sampai pada pengetahuan akan yang ilahi, dan melalui pengetahuan akan yang ilahi kita sampai pada hidup kekal. Hidup yang kekal sebagaimana ditulis oleh Yohanes dalam suratnya; "Inilah hidup yang kekal itu, yaitu bahwa mereka mengenal Engkau satusatunya Allah yang benar, dan mengenal Yesus Kristus yang telah Engkau utus." (1 Yoh. 17:3). Richard menyimpulkan bahwa hidup tentu berasal dari iman, tetapi hidup juga berasal dari pengetahuan. Dari iman datang hidup yang secara aktual kita hidupi dan menuju kebaikan, semantara dari pengetahuan datanglah hidup yang ditujukan pada masa depan, di mana kita akan hidup dalam kebahagiaan. ${ }^{46}$ Mutua-litas (antara iman dan hidup) ini bersimbio-sis dalam pribadi manusia yang dipanggil sebagai orang Kristiani, murid-murid Kristus.

\section{KESIMPULAN DAN TANGGAPAN}

\section{Kesimpulan}

Sejauh pembacaan kami, kiranya Richard dapat digolongkan sebagai seorang pemikir spekulatif kontemplatif. Dasar pemikiran kami adalah di sana-sini terlihat dengan jelas bagaimana uraian kontemplasi yang tidak hanya merenung mengenai Allah, 
tetapi juga merefleksikan atau membangun pengetahuan akan Allah. Riachar terhitung sebagai penulis spiritual yang terpandang pada Abad ke XII. Dante Aligeri mengatakan bahwa Richard "is more contemplation then human." 47 Selain itu Bonaventura pada abad XIII memandang Richard sebagai master kontemplasi "modern" pada zaman itu, yang dapat disandingkan dengan penulis kontemplatif terkenal pada abad-abad awal seperti Deonisius pseudo-Aeropagita. ${ }^{48}$

Pertama, kontemplasi. Kontemplasi merupakan jalan di mana manusia dapat naik dan mencapai realitas ilahi atau realitas yang kekal. Seluruh daya yang ada pada manusia yang mancakup imajinasi, rasio dan intuisi membantu manusia dalam berkontemplasi untuk sampai pada surga kediaman Allah. Pencapaian ini hanya dapat terjadi melalui kontemplasi spiritual. Tiga tahap yang harus dilalui oleh manusia adalah: Tahap Pertama, manusia dapat berangkat dari hal-hal yang tampak (sensible things) dengan imajinasinya. Melalui imajinasinya, ia dapat memikirkan dan mengagumi realitas sensible atau ciptaan yang ada di sekitarnya. Tahap Kedua, melalui meditasi manusia dapat menimbang atau menyilidiki realitas sensible dengan rasionya. Kemudia, ia dapat melampaui realitas sensible dengan merefleksikan Allah yang mewahyukan diri dalam Kitab Suci. Pada akhirnya, ia diantar pada intuisi, yaitu Tahap Ketiga, di mana ia dapat beristirahat dalam kekekalan. Dengan jalan imajinasi, meditasi dan kontemplasi manusia dapat naik secara spiritual ke dalam surga. Di sana, ia dapat merasakan kekekalan bersama Allah; di sana, ia akan mengetahui bahwa Allah adalah Sang Kebenaran Sejati dan Kristus adalah yang diutus oleh Allah ke dalam dunia melalui jalan inkarnasi.

Kedua, pengetahuan akan Allah. Titik berangkat refleksi akan realitas ilahi atau realitas kekal, adalah refleksi atas realitas kontingen. Realitas kontingen menunjukkan kepada kita bahwa ada realitas yang niscaya ada, dan yang bersifat kekal. Realitas yang kekal itu merupakan sumber segala sesuatu dan keberadaannya berasal dari dirinya.
Sementara realitas yang kontingen menerima keberadaanya dari realitas yang kekal.

Akan tetapi pemahaman akan realitas ilahi membutuhkan iman. Mengapa iman? Sebab, menurut Richard, iman adalah dasar dan sumber segala kebaikan, sementara pengetahuan merupakan perwujudan dan kesempurnaan. Manusia harus mempunyai iman yang kokoh, yang dapat mengantarnya kepada pengetahuan atau pemahaman akan yang ilahi, yang merupakan esensi dari iman. Berhadapan dengan realitas sensible manusia dapat memahami dengan pengalaman indrawi dan juga rasio. Dalam arti ini, pengetahuan itu dapat dicapai dengan pengalaman indrawi manusia, rasio dan iman. Melalui pengalaman indrawi manusia dapat mencapai pengetahuan yang temporal, sementara melalui rasio dan iman manusia dapat mencapai pengetahuan yang abadi.

\section{Tanggapan}

Pertama, patut diapresiasi pemikiran atau refleksi kontemplatif dan teologis dari Richard. Suatu refleksi teologis yang pada hemat kami, lahir dari permenungan atau kontemplasi yang mendalam akan yang ilahi. Selain itu, refleksi teolgois Richard juga lahir dari permenungan yang mendalam akan Kitab Suci; studinya akan tradisi atau warisan para bapa Gereja; dan studi atas literatur pagan. Kedua, pemikiran Richard mempunyai pengaruh yang besar pada para tokoh di kemudian hari. Salah seorang teolog Abad XIII dari Sekolah Fransiskan yang konon dipengaruhi oleh gaya berpikir Richard adalah Giovanni Fidanza atau Bonaventura. Grover A. Zin dalam pengantarnya atas karya Twelve Patriarch, Mystical Ark, on The Trinity mengatakan refleksi mistik Bonaventura dalam Itinerarium sangat dipengaruhi oleh Richard, terutama refleksinya mengenai enam jalan kontemplasi. ${ }^{49}$

Ketiga, kontempalsi, iman dan pengetahuan akan Allah sebagaimana dijelaskan Richard sangat membantu kita dalam dua hal. Pertama, cara-cara kontemplasi itu membantu kita dalam berkontemplasi dan berdiscermen mengenai hidup saat ini 
dalam hubungan kita dengan Allah. Melalui imajinasi, meditasi dan kontemplasi kita dapat merefleksikan dan merenungkan Allah, serta dapat mendekatkan diri kita kepada Allah. Kedua, iman yang selalu mencari pemahaman dan yang kemudian membawa kita untuk sampai kepada Allah penting dalam kehidupan kita sebagai orang beriman.

Keempat, metode berteologi Richard yang berangkat dari doa, kontemplasi dan studi yang mendalam atas Kitab Suci, warisan para bapa Gereja dan studi filsafat merupakan inspirasi untuk berteologi pada zaman ini. Berteologi pada zaman ini,

\section{CATATAN AKHIR}

G.R. Evan, "Anselm of Canterbury" dalam Augustine through the Ages: An Encyclopedia, diedit oleh Allan Fitzgerald, O.S.A, cs. (New York: Cambridge, 1999), 23-24.

2 Tidak jarang Agustinus Hippo ditempatkan pada periode zaman klasik, yang berarti sebelum Abad Pertengahan, sekurang-kurangnya tokoh besar ini menjembatani antara periode klasik (antik) dengan periode Abad Pertengahan.

3 Richard of Saint Victor, The Trinity Translation and Commentary by Ruben Agelici (Oregon: Casade Books, 2011), 65-66.

4 Biografi Richard ini ditulis dengan memanfaatkan beberapa sumber: Sr. M. Dominica Melone, Lo Spirito Santo nel De Trinitate di Riccardo di Vittore; Rick Van Nieuwenhove, An Introduction to Medieval Theology; R. Angelici, Richard of Saint Victor on the Trinity; "Richard of Saint-Victor" dalam Encyclopedia Britanica, dari (https://www.britannica.com/biography/Richard-of-Saint-Victor) diunduh pada 18 Maret 2018; 20:00 WIB.

5 An Introduction to Medieval Theology menyatakan bahwa Hugo lahir sekitar akhir abad XI, dan wafat 11 Febr. 1141. Karyanya disebut De Sacramentis Christiane Fidei. Lihat juga, Ritva Palmén, "The Experience of Beauty: Hugh and Richard of St. Victor on Natural Theology," dalam Journal of Analytic Theology, Vol. 4, May 2016. https: //www. google.co.id/search?A+Hugh + and + Richard + of + St. +Victor + on + Natural+Theology\&oq $=$ The + Experien ce + of + Beauty. (Diunduh 10 Maret 2018, pkl. 20:00 WIB), 235-236.

6 Ruben Angelici, English Translation and Commentary to Richard of Saint Victor on the Trinity, (bagian I, Komentar atas karya Richard dari St. Viktor), 5.

7 Lih. Ruben Angelici, Richard of Saint Victor on the Trinity, 3-4. menurut hemat kami, mesti berakar pada Kitab Suci, memperhatikan dengan saksama tradisi suci, dan juga studi lintas ilmu, agar refleksi teologis tidak terlepas dari inti iman kita, dan selalu kon(multi)tekstual.

Kelima, pengetahuan akan Allah yang berlandaskan pada iman, menurut kami menarik apa yang dikemukakan oleh Richard. Richard memperlihatkan kepada kita bahwa iman mengajarkan segala kebenaran yang bisa dipercaya. Iman terinspirasi oleh rahmat dalam pencaraian spiritual kita akan investigasi rasional yang dapat membawa kita dekat dengan Allah, di mana keselamatan itu ditemukan.
8 The Editor of Encyclopedia Britannica, "Richard of Saint-Victor" dalam Encyclopedia Britannica, Last Updated:3-3-2018.https://www.britannica.com/biography/Richard-of-Saint-Victor, (diakses pada 18 Maret 2018, pkl. 20:00 WIB).

9 Maria Dominica Melone, Lo Spirito Santo nel De Trinitate di Riccardo di Vittore (Roma: Pontificium Athenaeum Antonianum, 2001), 16.

10 Pseudo-Deonisius, The Divine Name sebagaimana dikutip oleh A. Sunarko, Allah Tritunggal Adalah Kasih: Tinjauan Historis Sistematik (Yogyakarta: Maharsa Artha Mulia, 2017), 73

11 Bdk. R. Angelici dalam komentarnya atas Richard of Saint Victor on the Trinity, 4-5.

12 Lihat, Richard of Saint Victor, The Twelve Patriarchs; The Mystical Ark; Book Three of The Trinity, Translation and Introduction by Grover A. Zin (New York: Paulist Press, 1979), 4-5.

13 R. van Nieuwenhove, An Introduction to Medieval Theology, 137.

14 Interpretasi Tropologi, artinya interpretasi figuratif (atau kiasan) atas teks Kitab Suci sebagai sumber moral yang dapat menuntun orang pada tindakantindakan moral. (Lihat, Oxford Living Dictionaries, https://en.oxforddictionaries.com/definition/tropology, (diakses pada 20 Maret 2018, pkl. 20:00 WIB))

15 Richard of Saint Victor, The Twelve Patriarchs, sebagaimana dikutip oleh Grover A. Zinn dalam pengantarnya atas Richard of Saint Victor, The Twelve Patriarchs; The Mystical Ark; Book Three of The Trinity, 10-11.

16 Richard of Saint Victor, The Twelve Patriarchs, 12.

17 Richard of Saint Victor, The Twelve Patriarchs; The Mystical Ark; Book Three of The Trinity, 10-11.

18 Richard of Saint Victor, Mystical Ark I.7. Sebagaimana dikutip oleh R.V. Nieuwenhove dalam An Introduction to Medieval Theology, 138

19 Richard of Saint Victor, Mystical Arch, I.4. 
20 Richard of Saint Victor, Mystical Arch, I.4.

21 Richard of Saint Victor, Mystical Arch, I.4.

22 Richard of Saint Victor, Mystical Ark. I.6, sebagaimana diuraikan oleh Rick Van Nieuwenhove dalam An Introduction to Medieval Theology, 139.

23 Richard of Saint Victor, The Twelve Patriarchs; The Mystical Ark; Book Three of The Trinity, 22-26.

24 Bdk. Richard of Saint Victor, The Mystical Ark I. 6.

25 Lihat juga, Rik Van Nieuwenhove, An Introduction to Mediavel Theology, 138-140.

26 Richard of Saint Victor, The Mystical Ark I. 8.

27 Bdk. The Editor of Encyclopedia Britannica, "Richard of Saint-Victor" dalam Encyclopedia Britannica, Last Updated: 3-3-2018. Diakses pada 18 Maret 2018.

28 Bdk. Richard of Saint Victor, On The Trinity, 66-69.

29 Lihat, Todd D. Vasquez, The Art of Trinitarian Articulation: A Case Study on Richard of St. Victor's de Trinitate, (Thesis and Dissertation) (Chicago, Illinois: Loyola University Chicago, 2009), 63.

30 Bdk. Todd D. Vasquez, The Art of Trinitarian Articulation, 63-64.

31 Richard of Saint Victor, The Trinity (I.4), 75-76.

32 Lihat, R. Angelici dalam komentarnya atas The Trinity, 17.

33 Agustinus, Religione, XXIV.45.

34 Agustinus, Trinity, XV.2.2. Sebagaimana dikutip oleh Ruben Agelici dalam komentarnya atas Trinitas Richard dari Santo Viktor, 18.

35 Terjemahan ayat ini berdasarkan pada terjemahan dari bahasa Yunani ke Latin LXX Vulgata (dari Nisi credideritis, non intelligetis). Sementara terjemahan baru untuk ayat ini menurut LBI (tahun 1976) adalah "Jika kamu tidak percaya, sungguh, kamu tidak teguh jaya."

36 Anselmus Canterbury, "On the Incarnation of the Word," In Anselm of Canterbury: The Major Work, ed. by B. Davies and G. R. Evans (Oxford: Oxford University Press, 1998), 235-36.

37 Richard of Saint Victor, The Trinity, 67.

38 Dalam The Trinity (I.3).

39 Richard of Saint Victor, The Trinity, (I.1), 73.

40 Richard of Saint Victor, The Trinity, (I.4), 75

41 Richard of saint Victor, The Trinity, (I.12), 81-82.

42 Richard of Saint Victor, The Trinity, (I.8.), 79.

43 Richard of Saint Victor, The Trinity, (I.5), 76.

44 Rik Van Nieuwenhove, An Introduction to Medieval Theology, 141.

45 Richard of Saint Victor, The Trinity, 65

46 Richard of Saint Victor, The Trinity, 65-66.

47 Dannte, Paradiso 11:32, Sebagaimana dikutip oleh Grover A. Zin dalam pengatarnya atas karya The Twelve Patriarch, The Mystical Ark, and The Book Three of Trinity, 1.

48 Boanventura, De Reductione artium ad Theologiam 5, dikutip oleh Grover A. Zin dalam pengantar The Twelve Patriarch, The Mystical Ark and Book Three of Trinity, 1.
49 Lihat komentar Grover A. Zin dalam Richard of Saint Victor, The Twelve Patriarchs; The Mystical Ark; Book Three of The Trinity, 4-5. Selain itu, refeleksi Bonaventura mengenai Trinitas terutama dalam pandangannya mengenai Allah Roh Kudus sebagai kasih bersama (Condilectio) sangat dipengaruhi oleh refleksi teologis Trinitas Richard. Lihat, Andreas B. Atawolo, Hasrat Allah akan Jiwa Manusia: Belajar dari Teologi Bonaventura (Jakarta: OBOR, 2017), 67).

\section{DAFTAR RUJUKAN}

Anselmus of Canterbury. "On the Incarnation of the Word," In Anselm of Canterbury: The Major Work (Edited by B. Devies and G. R. Evans). Oxford: Oxford University Press, 1998.

Atawolo, Andreas B. Hasrat Allah akan Jiwa Manusia: Belajar dari Teologi Bonaventura. Jakarta: OBOR, 2017.

Chenu, Marie-Dominique. La teologia nel dodicesimo secolo. (A cura di Paolo Vian. Introduzione di Inos Biffi). Milano: Editoriale Jaca Book spa, 1992.

Evan, G.R. "Anselm of Canterbury." In Augustine through the Ages: An Encyclopedia. (Diedit oleh Allan Fitzgerald, O.S.A, dkk.). New York: Cambridge, 1999: 23-24.

Melone, Maria Dominica. Lo Spirito Santo nel De Trinitate di Riccardo di Vittore. Roma: Pontificium Athenaeum Antonianum, 2000.

Nieuwenhove, Rik van. Introduction to Medieval Theology. New York: Cambridge University Press, 2012.
Oxford
Living
Dictionaries, https://en.oxforddictionaries.com/defi nition/tropology, diakses pada 20 Maret 2018, pkl. 20:00 WIB. 
Palmén, Ritva. "The Experience of Beauty: Hugh and Richard of St. Victor on Natural Theology." Dalam Journal of Analytic Theology. Vol. 4, May 2016, https://www.google.co.id/search?A+H ugh + and + Richard + of + St. + Victor + on + Natural + Theology\&oq $=$ The + Ex perience + of + Beauty. Diunduh pada tanggal 10 Maret 2018, pkl. 20:00 WIB, 235-236.

Richard of Saint Victor. The Twelve Patriarchs: The Mystical Ark; Book Three of The Trinity. (Translation and Introduction by Grover A. Zin). New York: Paulist Press, 1979.

\section{The Trinity.}

(Translation and Commentary by Ruben Agelici). Oregon: Casade Books, 2011.

Sunarko, Adrianus. Allah Tritunggal Adalah Kasih: Tinjauan Historis Sistematik. Yogyakarta: Maharsa Artha Mulia, 2017.
The Editor of Encyclopedia Britannica, "Richard of Saint-Victor". Dalam Encyclopedia Britannica. Last Updated:3-3-2018; https://www.britannica.com/topic/Test aments-of-the-Twelve-Patriarchs.

Diakses pada 18 Maret 2018, pkl. 20:00 WIB.Vasquez, Todd David. 2009. "The Art of Trinitarian Articulation: A Case Study on Richard of St. Victor's De Trinitate." (Thesis and Dissertation). Chicago, Illinois: Loyola University Chicago.

Vilanova, Evangelista. 1992. Storia della teologia Cristiana. vol. 3 (1992). (Traduzione di Carlo Chiecchi; Revisione a cura dell'edizione italiana di Stefano Cavallotto; Collaboratori redazionali: Giovanna Vitale e Lorenzo De Lorenzi). Editorial Herder S.A.: Barcelona. 
